\title{
魚類筋原繊維の収縮性とATPase 活性の関係に関する基礎的研究
}

\author{
阪本正博・新井健一
}

(1979 年 8 月 1 日受理)

\begin{abstract}
A Fundamental Study on Relationship between ATPase Activity and Contractile Property of Fish Myofibrils

Masahiro SaKamoto*1 and Ken-ichi Arar*2
\end{abstract}

Fish myofibrils were prepared for the study on the relation of their ATPase activity to contractile properties, especially in the presence of $\mathrm{Mg}$ or $\mathrm{Ca}$ ion. The degree of contraction of the myofibrils was measured in relative terms by centrifuging the myofibrillar system at $1,000 \mathrm{rpm}$ for 20 minutes, and then measuring the volumes of the fibril layer, in the absence and presence of ATP. The ATPase activity of myofibrils under the same condition as above was also assayed, separately.

When $\mathrm{Mg}$ ion alone was added as divalent cation to our myofibril preparation, it had little or no effect on the degree of contraction and on the rate of ATP splitting as well. Further addition of EDTA to this Mg system, however, resulted in considerable inhibition of ATPase activity and in the complete inhibition of contraction. On the other hand, $\mathrm{Ca}$ ion alone, even at high concentration, somewhat reduced the degree of contraction, although it allowed a very high rate of ATP splitting. These results showed that the fish myofibrillar system closely resembled that of rabbit in its reaction towards ATP and divalent cations.

Three myofibril preparations which consisted of different sized fragments of fibrils were obtained by using differential centrifugation. No differences was found in contractile properties and in their ATPase activity between them.

魚類の筋原瀻維(以下，Mf と略す) に関する研究は, 加藤らがその調製を試及てか.ら文，非常に多く行われる ようになつた。すなわち，Mf は生筋のモデルとして 優れており取り扱いやすい利点を持つているからである う2)。すで著者らはその ATPase 活性について基䂢的

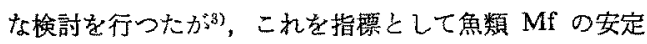
性火関する研究 ${ }^{3-5}$ 扣上び機能に関する研究などが報告 されている ATP に上つて収箱することは良く知られていることで あるが，魚類 Mf の収縮に関する研究怯全く行われてい， ない。一般に，Mf D収縮能の湘定は筋節の長さの变 化を顕微鏡視野で算定したり て行われている10)。本研究ではるつとる単純な試及で はあるが簡便な方法として知られている ATPによる Mfの容積变化から判定す名武みを追試した。初めにMf の収維（容積変化）が強く起こる反応条件を見出すため 基礎的な検詰寺行い，次に同条件下における ATPase 活性との関係を明らかにしよらとした。またサイズの
異なる（微細をたは粗大）Mf 断片から成る Mf 標品の 収縮性とATPase 活性について子比較検討した。

\section{実驗方法}

魚類笳原織維の調製法 本実験で使用したMf の大部 分は，先に加藤らが報じた方法に準じて調製しだ。す なわら, 生鮮魚肉を $0.1 \mathrm{M} \mathrm{KCl} \sim 40 \mathrm{~mm}$ Tris- $\mathrm{HCl}(\mathrm{pH}$ 7.5) と共に日本精機製ホモジナイザーにより，充分に冷 却乙 30 秒間の休止時間を括きながら， 1 分間ずつ計 6 分闒ホモジナイズした後， $3,000 \times \mathrm{g}$ で 10 分間遠心分離 して上澄み夜を唅てる操作を数回くり加えし，最後に一 層のガーゼで沪過して結合組織などを除き Mf 標品とし た（標品 a とする）。の操作は，いわゆる遠心分画 法 ${ }^{11,12)}$ を採用して拈らず，Mf を集めるために用いる橾 心力が従来の場合と買なつている。しかし，娚製した Mf 祭品は生化学的炕均質で定量的な取扱いが可能であ $\eta^{1)}$ ，ATPase の純度特よび一般的性質は従来の報告と 同でであつた。一方，上記の方法と翼なる遠心力で集め

*1 Present address; Department of Dermatology, University of California San Francisco, School of Medicine, San Francisco, Calif.

*2 北海道大学水産学部生物化学教室 (Laboratory of Biochemistry, Faculty of Fisheries, Hokkaido University, Hakodate 041). 
た Mf 標品も本実験の中の一部 (Table 1 k示寸実験)

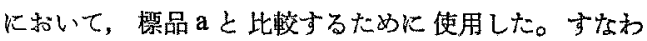
ち，上記の Mf 標品 a の晸濁夜を $300 \times \mathrm{g} て ゙ 5$ 分間遠心

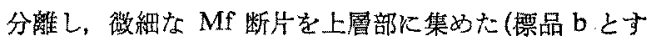
る。ここで沈段する粗いサイズの Mf は再び $0.1 \mathrm{M}$

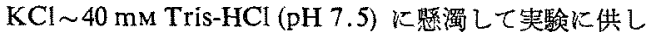
た(標品 $\mathrm{c}$ とする)。実験に用いた魚種は主にコイ(Carp， Cyprinus carpio) であるが,マガレイ(Flat-fish, Limanda angustirostris),スタトウタラ(Alaska pollack, Theragra chalcogramma) 仕加熱变性の比㣀の実験に使用しだ。

筋原織維の收縮率の測定法 基礎的な検討を行つた 後，採用した測定条件は $0.09 \mathrm{M} \mathrm{KCl}, 5 \mathrm{mM} \mathrm{MgCl}_{2}$, $0.1 \mathrm{~mm} \mathrm{CaCl}, 36 \mathrm{~mm}$ Tris-HCl (pH 7.5), Mf タンパ ク質 $3 \sim 7 \mathrm{mg} / \mathrm{ml} ， 3 \mathrm{~mm}$ ATP (いずれる終濃度) であ る。先ず ATP を除く混合液 $(9 \mathrm{~m} l)$ を目盛付きスピッ

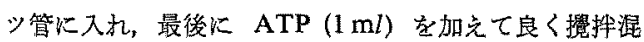
和 L, 1 分後に $2^{\circ} \mathrm{C}$ で $1,000 \mathrm{rpm}(185 \times \mathrm{g}), 20$ 分間遗 心分離して沈殿する Mf の占める容積を読みとつた。收 縮率の表示は次式似よつた。収縮率 $=\left[\left(V_{0}-V_{\mathrm{ATP}}\right) / V_{0}\right] \times$

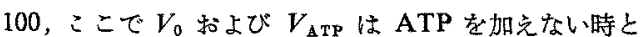
加六た時の Mf の容量である。新鮮肉から調整したMf の収縮率はほぼ 65 75\% であつた。

筋原繊維の収縮の形憼鹳察 ATP に上るMf の収縮 を NIKON S-Ke 型位相差顕殿鏡を使用し，室温で観察 した。すなわち，収縮率の測定に供した同し組成の Mf 㲜濁液をスライドグラス上にとり，その上のカバーグラ スの一端から ATPase 溶液を1滴渗み込ませて Mf の 収縮を観察し，写真撮影を行つた。

筋原瀻維 ATPase 活性の測定 Mf の收縮率と ATPase 活性との関䌽を明らかにするため，Mf の収縮を行

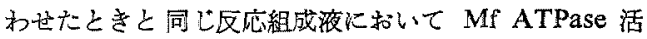
珄を別简に睍定した。すなわら，特別な目的の実験の 場合以外位, $0.09 \mathrm{M} \mathrm{KCl}, 5 \mathrm{mM} \mathrm{MgCl}_{2}, 0.1 \mathrm{mM} \mathrm{CaCl}_{2}$, $36 \mathrm{~mm}$ Tris- $\mathrm{HCl}$ (pH 7.5), $3 \mathrm{mM}$ ATP, $3 \sim 7 \mathrm{mg} / \mathrm{ml}$ タ ソパク質の混液で $2^{\circ} \mathrm{C}$ に怙いて生成する無機り几酸を 比色定量した 133。また，Mf タンパク質はビウレット法 により此色定量しだ4)。

\section{結果}

ATP による筋原織維の容皘変化に影響する各種因子 について (1)遠心分離の条件 収縮に伴う Mf の容磧変 化を測定する遠心分離の条件は，多数試料を同時酒涀定 するための所要時間などを考湭して 20 分間と定め，Mf の收縮率に及活す遠心力（国産冷却遠心機 H-103 RS 型 のローターの回轱速度で表放した) の影響を検討した (Fig. 1)。この実験ではニイ Mfのタンパク質濃度が3.0 および $6.3 \mathrm{mg} / \mathrm{m} l$ の場合の収縮の結果を示したが，い

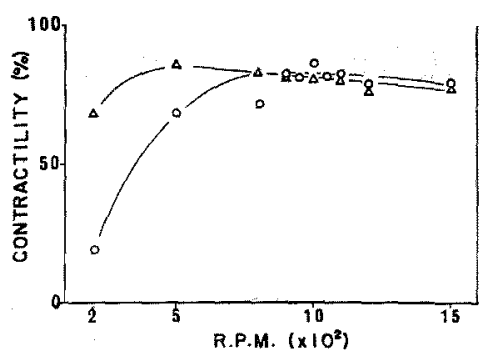

Fig. 1. Effect of centrifuging force used for sedimentation of fibril layer, on the contractility of carp myofibrils.

Fresh muscle was homogenized with a cold 0.1 м KCl-40 mM Tris-HCl (pH 7.5). The myofibrils were sedimented by centrifugation at $3,000 \times \mathrm{g}$ for 10 minutes. They are then washed throughly to remove the soluble proteins with the same cold $\mathrm{KCl}$-buffer solution. Finally, the myofibrils were separated from connective tissue and intact fibers by filtration through a layer of gauze.

The degree of contraction of myofibrils was demonstrated in relative terms by centrifuging the myofibrillar system at various speeds (rpm) for 20 minutes and at $2^{\circ} \mathrm{C}$, and then measuring the volume of the fibril layer, in the absence and presence of ATP. The assay system for the contractility of myofibrils was $0.09 \mathrm{M} \mathrm{KCl}, 36 \mathrm{mM}$ Tris-HCl (pH 7.5), $5 \mathrm{~mm}$ $\mathrm{MgCl}_{2}, 0.01 \mathrm{mM} \mathrm{CaCl}, 3 \mathrm{~mm}$ ATP where added, and $6.3 \mathrm{mg} / \mathrm{ml}(O)$ or $3.0 \mathrm{mg} / \mathrm{ml}(\triangle)$ of protein.

Contractility $=\left[\left(V_{0}-V_{\Delta T P}\right) / V_{0}\right] \times 100$, where $V_{0}$ and $V_{\text {Atr }}$ represent the volumes of myofibrils in the absence and presence of ATP, respectively.

ずれの場合る遠心力が 900 1,500 rpm(約 150 400×g) において一定の高い収縮率を示した。なお，遠心力を強 めると，ATP を加えないときの Mf の容積が小さくな るため収縮率は低值となり，一方，遠心力を弱くする と, ATP 派加後の Mf の容積がなかなか安定した值に 到至せず一定の 收縮率が得られにくくなる。したがつ て，本実験では特に述べ方時老除き， $1,000 \mathrm{rpm}$ で 20 分間遠心分離して Mf の容量を測つた。

(2) $\mathrm{KCl}$ 濃度 ニイ Mf の收縮に及ぼす $\mathrm{KCl}$ 濃度 の影響を次に検討した。また，同条件下に怙ける Mf ATPase 活性6別筒に湘定した (Fig. 2)。この結果によ ると，Mf の収縮は 0.08 0.1 M KCl に扣いて強く起 こり $0.12 \sim 0.14 \mathrm{M} \mathrm{KCl}$ では起こりKくからた。特他 $0.1 \mathrm{M}$ から $0.12 \mathrm{M} \mathrm{KCl}$ の濃度轮因て収縮率の低下が 著しいが、この現像は同条件下の ATPase 活珄の著し い低下と良く相関していた。 Mf の $\mathrm{Ca}^{2+}$-ATPase 活性 は $0.1 \mathrm{M}$ 以上の高 $\mathrm{KCl}$ 濃度下では著しく低下すること 


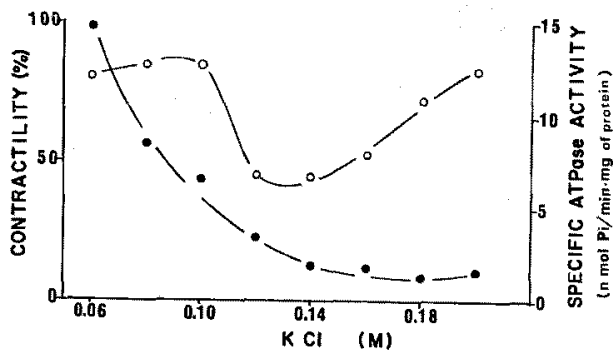

Fig. 2. Effects of $\mathrm{KCl}$ concentration on the contractility and the ATPase activity of carp myofibrils.

The assay system for the contractility $(0)$ of myofibrils was the same as in Fig. 1, except that $6.4 \mathrm{mg} / \mathrm{ml}$ of protein and various concentrations of $\mathrm{KCl}$ were used. The volume of fibril layer in the system was measured by centrifuging at 1,000 rpm for 20 minutes. The demonstration of the contractility was the same as in the legend of Fig. 1.

The ATPase activities (O) of myofibrils under the various $\mathrm{KCl}$ concentrations as above were also measured.

はすで知られているが1)，本実駼条件 $\left(5 \mathrm{mM} \mathrm{MgCl}_{2}\right.$,

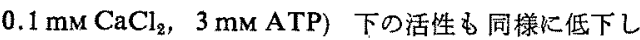
た。なお， $\mathrm{KCl}$ 濃度が 0.16〜0.2 M 飞机いて取縮率 が倩が高値を示すのは，ATP を加える前の Mf の容 積がこの $\mathrm{KCl}$ 浱度下で明らが増加、才なわら，膨潤 する事実が認められたので，あくまでも見かけ上の增加 にすぎいと言らことが出来よう。

(3) ATP, $\mathrm{Mg}^{2+}$ および $\mathrm{Ca}^{2+}$ 從来から Mf の収縮に とつて必要な因子は $\mathrm{ATP} と ， \mathrm{Mg}^{2+}, \mathrm{Ca}^{2+}$ の様な二価 正イオンであることが知られている。そこで，取縮を行 わせるときの他の条件を一定に保持し，ATP(Fig. 3)， $\mathrm{Mg}^{2+}$ (Fig. 4) または $\mathrm{Ca}^{2+}$ (Fig. 5) の濃度を変化させ， コイ Mf の収縮率に及注す影響を検討した。ての結果は コイ Mf が最高の取縮率を示すたるにはATP 3 m $\mathrm{Mg}^{2+}$ は $5 \mathrm{mM}$ (いず扑終浱度) 加党ると良いことを 示崚した。また， $\mathrm{Ca}^{2+}$ は別に加える必要がないといら 結果であつたが，実験条件を明らかにして蛒くために $0.1 \mathrm{mM}$ 派加して収察率を测定することにした。なお， Fig. 3〜6 に示したように，本実験で使用したコイ Mf 標品恃特に $\mathrm{Mg}^{2+} ゃ \mathrm{Ca}^{2+}$ 添加しなくとも，ATPによ つてある程度強く收縮した。そこで収縮に及ぼす $\mathrm{Mg}^{2+}$ や $\mathrm{Ca}^{2+}$ の必要珄を確めるために，EDTA (ethylene diamine tetra acetic acid) $\measuredangle$ EGTA (ethylene glycol bis ( $\beta$-aminoethylether)- $N$ - $N^{\prime}$-tetra-acetic acid) な のキレート剂を用いてさらに検討した (Fig. 6)。すなわ ち、 $\mathrm{Mg}^{2+}$ を含まない反応混液に EDTA を加劣ると,

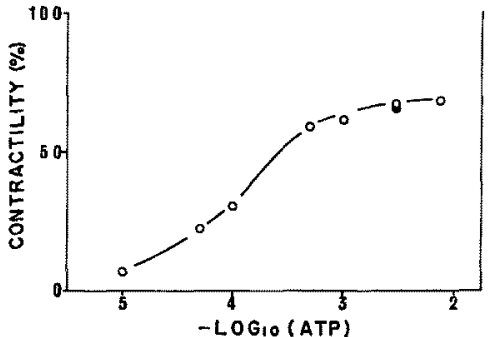

Fig. 3. Effect of ATP concentration on the contractility of carp myofibrils.

The assay system for the contractility of carp myofibrils was the same as in Fig. 1, except that $6.4 \mathrm{mg} / \mathrm{ml}$ of protein and various concentrations of ATP were used (O). The volume of fibril layer in the assay system was measured by centrifuging at $1,000 \mathrm{rpm}$ for 20 minutes. The demonstration of the contractility was the same as in the legend of Fig. 1. As a control (c), the contractility of myofibrils with ATP in the absence of $\mathrm{MgCl}_{2}$ and $\mathrm{CaCl}_{2}$ was also measured (O).

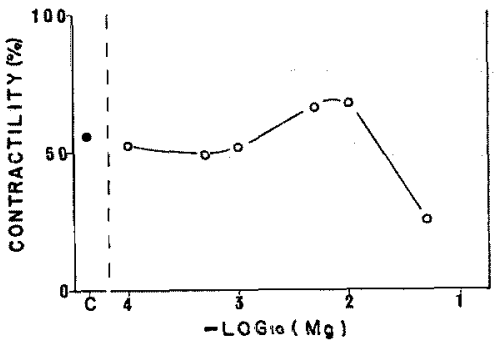

Fig. 4. Effect of $\mathrm{MgCl}_{2}$ concentration on the contractility of carp myofibrils.

The assay system for the contractility of carp myofibrils was the same as in Fig. 1, except that $6.4 \mathrm{mg} / \mathrm{ml}$ of protein and various concentrations of $\mathrm{MgCl}_{2}$ were used (O). The other condition and method were the same as in Fig. 3. The demonstration of the contractility was the same as in the legend of Fig. 1. As a control (c), the contractility of myofibrils with ATP in the absence of $\mathrm{MgCl}_{2}$ only was also measured (O).

その濃度が增す大従いMfの取縮率は焦下し約 $1 \mathrm{mM} て$ 収縮は起こらなくなつた（別に測つた同一条件下の ATPase 活性も低下していた)。次に，収縮率を剆つた 同混液に $5 \mathrm{mM} \mathrm{Mg}^{2+}$ を加えると Mf の収縮率は元の值 まで回復した。一方， $\mathrm{Ca}^{2+}$ を含えでいない反応混液に EGTAを $5 \mathrm{~mm}$ 加えても収繀はほとんど坜制されない が、ATPase 活性は傼が低下したにこの結果はここで は図示しないが，後で Fig. 12 の一部として重ねて言及 


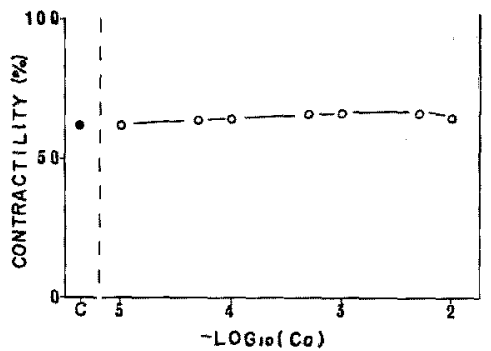

Fig. 5. Effect of $\mathrm{CaCl}_{2}$ concentration on the contractility of carp myofibrils.

The assay system for the contractility of carp myofibrils was the same as in Fig. 1, except that $6.4 \mathrm{mg} / \mathrm{ml}$ of protein and various concentrations of $\mathrm{CaCl}_{2}$ were used (O). The other condition and method were the same as in Fig. 3. The demonstration of the contractility was the same as in the legend of Fig. 1. As a control (c), the contractility of myofibrils with ATP in the absence of $\mathrm{CaCl}_{2}$ only was also measured (O).

する)。したがつて，魚類 Mf の収縮に和いて $\mathrm{Mg}^{2+} の$ 必要量はかなり多いが， $\mathrm{Ca}^{2+}$ は著しく微量にとどまる ように推定される。この結果はウサギなど他の動物の Mfやダリセリン処理筋で知られている二価正イオン（特 に $\left.\mathrm{Mg}^{2+} と \mathrm{Ca}^{2+}\right)$ の要求性と極めて良く俊ている2,16,19)。

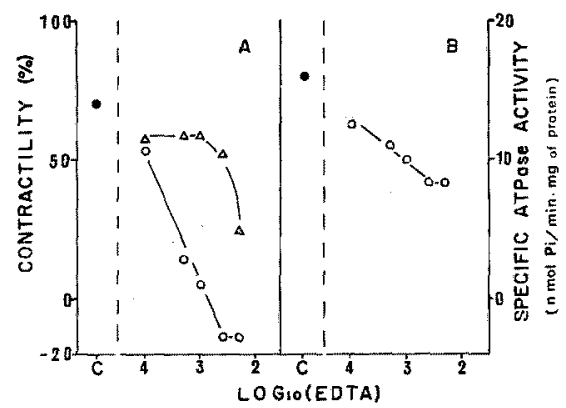

Fig. 6. Effects of EDTA on the contractility and the ATPase activity of carp myofibrils.

(A) The assay system for the contractility of carp myofibrils was $0.09 \mathrm{M} \mathrm{KCl}, 36 \mathrm{mM}$ Tris- $\mathrm{HCl}$ ( $\mathrm{pH} 7.5$ ), $6.2 \mathrm{mg} / \mathrm{ml}$ of protein, $3 \mathrm{~mm}$ ATP and various concentrations of EDTA (O). A further additional effect of $5 \mathrm{~mm}$ $\mathrm{MgCl}_{2}$ on the contractility in the same system containing EDTA as above, was measured $(\triangle)$. The other experimental condition and method were the same as in Fig. 3. The demonstration of the contractility was the same as in the legend of Fig. 1.

(B) The ATPase activities of myofibrils under the various conditions of (A) described above, were also measured at $2^{\circ} \mathrm{C}$.

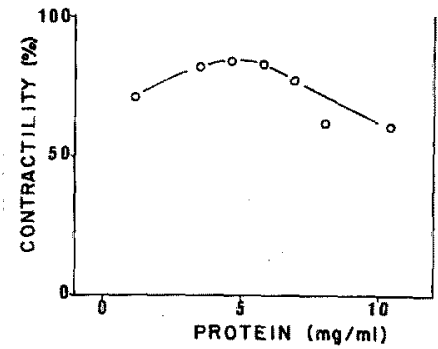

Fig, 7. Effect of protein concentration on the contractility of carp myofibrils.

The assay system for the contractility of carp myofibrils was the same as in Fig. 1, except that various concentrations of myofibrillar protein were used. The other experimental condition and method were the same as in Fig. 3. The demonstration of the contractility was the same as in the legend of Fig. 1.

(4) $p$-CMB ( $p$-chloro mercuribenzoate) $\mathrm{SH}$ 基阻 害剂として良く知られている $p$-CMBのコイ Mf の収縮 に及活す影響検討した。結果は图示しないが，p-CMB は Mf の収縮を強く抑制し同時に $\mathrm{Ca}^{2+}$-ATPase 活性 当低下していた。测定した $\mathrm{Ca}^{2+}$-ATPase 活性の反㐫条 件は $5 \mathrm{~mm} \mathrm{CaCl}, 100 \mathrm{mM} \mathrm{KCl}, 25 \mathrm{mM}$ Tris-maleate (pH 7.0)，1 mM ATP，温度 $=25^{\circ} \mathrm{C}$ である。ま， ATPase の完全失活他要する $p$-CMB 量は, Mf タンパ ク質の 54\% がミオシンK相当するとして計算すると7，

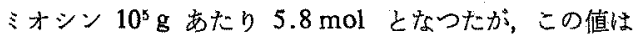
先にウサギおよびティラピアのミオシン $\mathrm{Ca}^{2+}$-ATPase

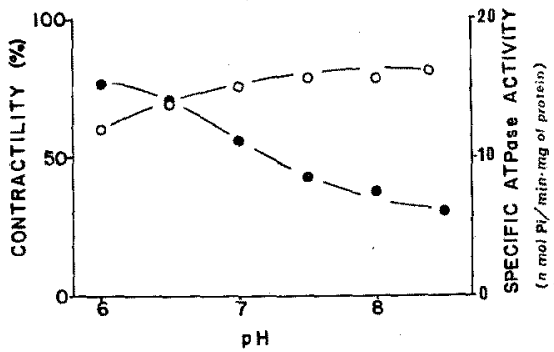

Fig. 8. Effects of pH on the contractility and the ATPase activity of carp myofibrils.

The assay system for the contractility of carp myofibrils was the same as in Fig. 1, except that $\mathrm{pH}$ of the system was changed from 6.0 to 8.7 using $50 \mathrm{~mm}$ buffer $(O)$. The other experimental condition and method were the same as in Fig. 3. The demonstration of the contractility was the same as in the legend of Fig. 1.

The ATPase activities (๑) of myofibrils under the various pH's as above, were also measured at $2^{\circ} \mathrm{C}$. 
のp-CMB による阻害から得られた結果と良く一致して (る ${ }^{17)}$ 。

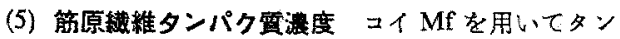
パク質淲度か゚収縮率に及ぼす影響を検討した (Fig. 7)。 これによると，Mf タンパク質として 3〜7 $\mathrm{mg} / \mathrm{ml}$ の浱 度にわたつて一定の收縮率を示す結果となつた。なお、 Mf のタンパク質濃度が高い力が，Mf の占わる容積が 大きいので正確な収縮率が得られ易かつた。

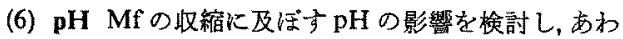
せて同一条件下の Mf ATPase 活性む測定した (Fig. 8)。 pH の調節は出来るだけ低温で行い，短時間で測定る終 えたが，その結果によると、コイ Mf の政縮は pH 6 付 近でやや弱いが $\mathrm{pH} 7.0$ 8.6 では強まりはほ一定の収 縮率を示した。なお， $\mathrm{pH} 9.5$ 以上では Mf の膨潤が見 られるが，pH 8.6 では認められないので収縮率の増加 は見がけ現象ではない。一方，ATPase 比活性は pH 7.0 以上で逆に低下寸る項向を示したが，大きな低下で はなく收縮をするためには充分な比活性を保持してい た。その比活性は，Fig. 7 の結果から 6 7 nmol Pi/ $\mathrm{min} \cdot \mathrm{mg}$ タンパク貿程度と推定される。

(7) 温度 魚類 Mf $の$ 取縮を測定する温度については， その不安定性を考慮して低温で行うことが好ましい。し かし，ここでは ATPにより Mf が收粳するときの温 度 $\left(2 \sim 35^{\circ} \mathrm{C}\right)$ と德心分離操作の温度 $\left(2^{\circ} \mathrm{C}\right.$ まは $\left.20^{\circ} \mathrm{C}\right)$ Kついて検討した。結果は図示しないが，前者は 5〜10 ${ }^{\circ} \mathrm{C}$ に抹いて相対的にやや高い収縮率を与文, 後者の場 合は $2^{\circ} \mathrm{C}$ と $20^{\circ} \mathrm{C}$ であまり変らなからた。

（8）その他の条件 Mfの収縮率の测定に影礐引る要因 として他にまだ考慮すべき因子があるように思われる。 たとえば，Mfと ATPを混合してからの経過時間の問 題がある。こ1 Mf の場合, ATP を添加しても混和し ないで和けば，头蔵 30 分後に㩭作を続行しても結果に なんらの影響も及ぼさなかつ。一方，ATP を混和後 遠心分離せずに 15〜30 分間にわたり放置し, その後遗 心分離して収緶率を求政場合は, 放置時間の経過に说 いやや低い収縮率を示すようになる。また，遠心分離終 了後 Mf の容積を読みとらずに放置すると，このときも 経過時間に従つてやや低い收縮率を示すよ5になつだ。 この埸合は Mf タンパク質湄度が高い方がその傾向か゚強 かつた。したがつて，ATP 混和後の遠心分離までの時 間杺よび遠心分離後 Mf 容量索読みとるまでの眭間は一 定にすることが大切である。ATPによるMfの收稚は 非常に速やかに進行することはすでに知られているが， ATP との反他次不完全な時や，遠心分離して Mf と ATP, $\mathrm{Mg}^{2+}, \mathrm{Ca}^{2+}$ 上の接触充る程度断つてから放置 する時に，どの上うに進さかは知られていない。なお， $\mathrm{Mg}^{2+}$ ¿ $\mathrm{Ca}^{2+}$ たけ高添加した場合は，時間経過にとも
なら収緶率の変化は見られなかつた。

以上述べた実験結果は，コイ Mfを使用して得たるの であるが，他にニジマス (Rainbow trout, Salmo gairdnerii irideus) やマダラ (Pacific cod, Gadas morhau macrocephalus) の Mf Kついて検討した結果も同しで あつた。

筋原雗維の収縮性亡 ATPase 活性の関係について すでに述べたように，Mf の収縮は 2 価正イオン特に $\mathrm{Mg}^{2+}$ の影響を強くうける。そこで $\mathrm{Mg}^{2+}$ 和よび $\mathrm{Ca}^{2+}$ 存在下の Mf の收縮率之 ATPase 活性を同一条件下で 別々に測定し，雨者の関係を検討した (Fig. 9)。先ず， Mf 標品に ATP だけを加えたとき $\left(\mathrm{Mg}^{2+}\right.$ と $\mathrm{Ca}^{2+}$ は 添加していない）の收䑿率は 69\%で，ATPase 此活性

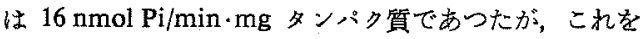

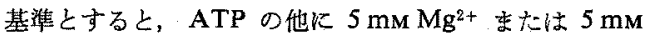
$\mathrm{Mg}^{2+}$ と $0.1 \mathrm{mMCa}{ }^{2+}$ を同時に加光たときは収縮率は やや高值となり，ATPase 西たやや活性化された。し かし， $\mathrm{Mg}^{2+}$ と $\mathrm{Ca}^{2+}$ 㬄加せずにATP と $5 \mathrm{mM}$ EDTA を加えたときは，収縮性および ATPase 活性は共比強 く抑制された。負の収樎率は ATPによるMfの膨潤を 表わすが後で考察する。EDTA の代りに 5 mM EGTA を加えたときは，収紑率はあまり変らないが ATPase活 性はやや抑制された。一方, ATP と $5 \mathrm{mM} \mathrm{Ca}^{2+} を$ 加

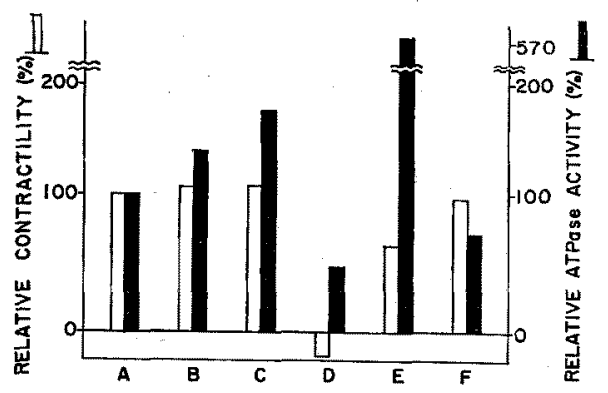

Fig. 9. Effects of divalent cations on the contractility and ATPase activity of carp myofibrils.

The contractility of carp myofibrils was measured in various systems $(\mathrm{A}-\mathrm{F}), \quad 0.09 \mathrm{M}$ $\mathrm{KCl}$; $36 \mathrm{~mm}$ Tris-HCl (pH 7.5); 3 mM ATP where added; $4.8 \mathrm{mg} / \mathrm{ml}$ of protein; temperature $=2^{\circ} \mathrm{C}$. (A) ATP, no $\mathrm{MgCl}_{2}$ and $\mathrm{CaCl}_{2}$; (B) ATP + $5 \mathrm{mM} \mathrm{MgCl}_{2}$; (C) ATP + $5 \mathrm{mM} \mathrm{MgCl}_{2}$ $+0.1 \mathrm{mM} \mathrm{CaCl}_{2}$; (D) ATP +5 mM EDTA; (E) ATP + $5 \mathrm{mM} \mathrm{CaCl}_{2}$; (F) ATP + 5 mM EGTA. The other experimental conditions and methods were the same as in Fig. 2. The demonstration of the contractility was the same as in the legend of Fig. 1. The ATPase activities of myofibrils under the same conditions as above $(\mathrm{A}-\mathrm{F})$ were assayed.

$\square$, contractility; $\mathbf{0}$, ATPase activity 
点たときは，收繀率はやや低下するが ATPase 活性は

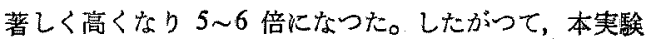
条件下では $\mathrm{Ca}^{2+}$ は Mf のATPase 強く活性化する

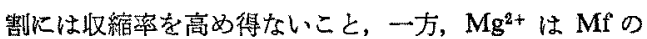
収縮にとつて必須ですり，ATPase と収縮性を同時に活 性化することる示唆する結果となつた。

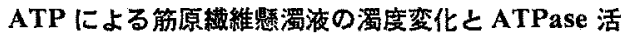
性の関係について ATPによる Mf の容積変化住非常 に隩く進行するため，収縮の度合(強さ)を知るために適 しているが，収縮の反応速度に関する知見は得られな い。そこで次に，Mf 彩濁液に ATP 添加したときに 起こる摆度変化を追跡する方法を試みた。この実験の条 件は Mf 馝濁液のタンパタ質濃度を低くし $(0.6 \mathrm{mg} / \mathrm{ml})$, 測定温度が高い(室温)他は容積变化を测定する方法と全 く同じにた。その結果はFig. 10 に示したが、これに

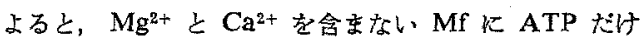

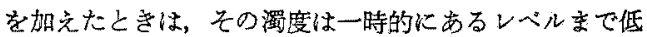
下するが再び上界しある程度まて回復した。また， $5 \mathrm{mM}$ $\mathrm{Mg}^{2+}$ なは $5 \mathrm{mM} \mathrm{Mg}^{2+}$ と $0.1 \mathrm{mM} \mathrm{Ca} \mathrm{Ca}^{2+}$ 存在下の $\mathrm{Mf}$ にATPを加えると，濁度の低下は著しく速く起こりを の度合も大きかつた。方， $5 \mathrm{mM} \mathrm{Ca}^{2+}$ 存在下の $\mathrm{Mf} K$ ATP t加劣ると，渴度は一時的に上鼠した後徐々に低 下するが，その度合は小さかつた。これらの実験は，容

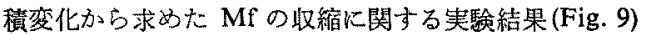
よりも，その速度に関する知見を多く与光るが，得られ

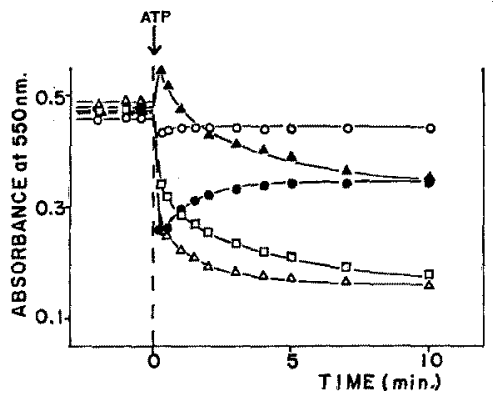

Fig. 10. Effect of divalent cations on the contractility, as measured by change in turbidity of carp myolibrils.

The contraction of the myofibrils was investigated by measuring the turbidity (absorbance at $550 \mathrm{~nm}$ in $1.5 \mathrm{~cm}$ light path) of the system after addition of ATP.

The assay system used was principally the same as that for volume change of myofibrils by ATP. $0.09 \mathrm{M} \mathrm{KCl} ; 36 \mathrm{~mm}$ Tris- $\mathrm{HCl}$ (pH 7.5); $3 \mathrm{~mm}$ ATP where added; $0.6 \mathrm{mg} / \mathrm{m} l$ of protein; temperature $=2^{\circ} \mathrm{C}$, (O) control, no ATP;

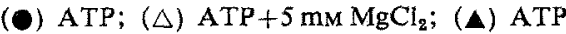
+5 $\mathrm{mM} \mathrm{CaCl}_{2} ;$ (口) ATP + $5 \mathrm{mM} \mathrm{MgCl}_{2}+0.1$ $\mathrm{mM} \mathrm{CaCl} \mathrm{C}_{2}$
た結論は本質的に同じであつた。すなわら，ATPによ

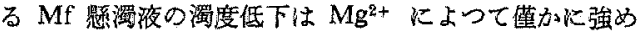
られる。 $\mathrm{Mg}^{2+}$ 存在下では $\mathrm{Ca}^{2+}$ のあらた添加效果は

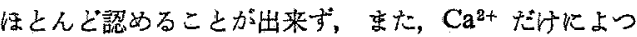
てはむしろ買常な变化が起こり，濁度は一㭙的に增加し た後低下するが， $\mathrm{Mg}^{2+}$ 存在下の場合とは道にその度合 は小さくなつた。

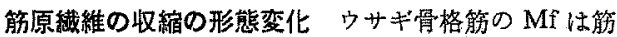
肉を硬直させてからホモジナイズすると良い標品が得ら れると報しられている2。 。た，筋肉をいつたん冷凍し てからホモジナイズして Mfを調製した例もあるが12), これらの方法の原理は刺激による Mf の取縮を避け，均 等な大きさの Mfを集めることによつて，䫓微鏡による

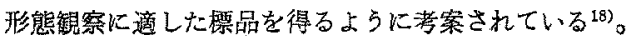
したがつて，別な見地からすれば，この方法では供試し た筋肉の一部分が標品化されるだけで収量はかなり低 く，その Mf 標品が供試筋肉全部位の性質を反映してい るかどうかについて疑問が残る。一方，著者らは経験的

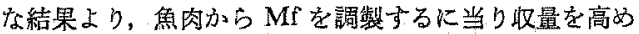
るために遠心分画法を採用していない、。たがつて， Mf の大きさは必らずしも均等ではなく，顕微鏡の視埋 に微細な Mf 断片やMf の集合体と思方九塊状の像が 見られる。そこで，このよらな Mf 標品と全体に均等な 大きさの Mf からなる標品の収縮率と ATPase 活性を 比較検討した（Table 1)。すなわら，コイ筋肉を $0.1 \mathrm{M}$ $\mathrm{KCl}(\mathrm{pH} \mathrm{7.5)}$ 溶液でホチジナイズし，遠心分離 $(3,000$ $\times \mathrm{g}, 10$ 分間) 後の上澄を搭て, 集めた沈殷を同上液に 再軗濁さむて遠心分離す尚操作を数回くりかえして得た

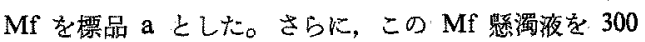

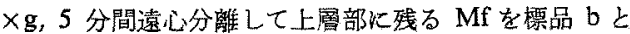
した。これは比較的销細で均等な大きさの Mf 標品とみ なされる12》。なお，この操作で沈殿した Mfを再懸濁し 標品 cとする。これら 3 種の Mf 標品の收縮率, ATPase 此活性和よび両者に対する $\mathrm{Mg}^{2+}$ と $\mathrm{Ca}^{2+}$ の效果などを 比べると，いずれも注とんど同じ結果になつだ。また， Mf の収縮を䫓微鏡下で観察すると (Fig. 11)，いろいろ の大きさの Mf 断片を含主標品 a たは Mf の集合体と 思われる塊状の像が見られるが (Mf 断片のそれぞれは 区别しにくい上，横紋す眀瞭に認めることができない， これは ATPによつてその外観を保つたま年で取縮して いるのが認められる $\left(\mathrm{A} ， \mathrm{~A}^{\prime}\right)$ 。対照のためにスケトウタ 亏 Mf の収維の場合も示すかi $\left(\mathbf{B}, \mathbf{B}^{\prime}\right)$ ， この Mf は標品 $\mathrm{b}$ の調製法によつたものである。この場合はMf 断片は分 散したままでATPによつて激しく收濰している。以上 速べたように，影微鏡的には各種の大きさと塊の Mf 標 品ではあつても，収繀率と ATPase 活性から見る限り いずれる同じMf とみなしらるといら結果となつた。な 
Table 1. The contractility and ATPase activity of different myofibril preparations from carp. The method for preparation of myofibrils (a) in $0.1 \mathrm{M} \mathrm{KCl}$ containing $40 \mathrm{~mm}$ Tris- $\mathrm{HCl}$ (pH 7.5) was the same as described in Fig. 1. The myofibril suspension (a) was then centrifuged at $300 \times \mathrm{g}$ for 5 minutes to separate the upper layer which consisted mainly of small fragments of myofibrils (b). The sediments collected by this centrifugation were resuspended in the same $0.1 \mathrm{M} \mathrm{KCl-buffer} \mathrm{(pH} \mathrm{7.5)} \mathrm{solution,} \mathrm{which} \mathrm{contained}$ mainly a larger fragments of myofibrils (c).

The contractility of myofibrils was measured in various systems. $0.09 \mathrm{M} \mathrm{KCl} ; 36 \mathrm{mM}$ Tris- $\mathrm{HCl}$ ( $\mathrm{pH} 7.5$ ); $3 \mathrm{~mm} \mathrm{ATP} \mathrm{where} \mathrm{added;} 4.8 \mathrm{mg} / \mathrm{ml}$ of protein; temperature $=2^{\circ} \mathrm{C}$. (A) ATP; (B) ATP $+5 \mathrm{~mm} \mathrm{MgCl}_{2}$; (C) ATP $+5 \mathrm{mM} \mathrm{MgCl}_{2}+0.1 \mathrm{~mm} \mathrm{CaCl}$; (D) ATP + $5 \mathrm{mM} \mathrm{CaCl}_{2}$; (E) ATP $+5 \mathrm{mM} \mathrm{MgCl}_{2}+5 \mathrm{mM} \mathrm{CaCl}_{2}$. The demonstration of the contractility was the same as in Fig. 1. The ATPase activities of myofibrils under the various conditions as above, were also measured.

\begin{tabular}{|c|c|c|c|c|c|c|c|}
\hline & \multirow{3}{*}{ Divalent cation } & \multicolumn{6}{|c|}{ Myofibrils } \\
\hline & & \multicolumn{3}{|c|}{ Contractility (\%) } & \multicolumn{3}{|c|}{$\begin{array}{c}\text { ATPase activity } \\
(\mathrm{nmol} \mathrm{Pi} / \mathrm{min} \cdot \mathrm{mg} \text { of protein) }\end{array}$} \\
\hline & & a & $\mathrm{b}$ & c & a & $\mathrm{b}$ & c \\
\hline A & none & 70 & 66 & 64 & 17 & 20 & 18 \\
\hline B & $5 \mathrm{mM} \mathrm{Mg}^{2+}$ & 73 & 73 & 71 & 19 & 24 & 20 \\
\hline $\mathrm{C}$ & $5 \mathrm{mM} \mathrm{Mg}^{2+}+0.1 \mathrm{mM} \mathrm{Ca}^{2+}$ & 73 & 73 & 72 & 23 & 20 & 25 \\
\hline D & $5 \mathrm{mM} \mathrm{Ca}^{2+}$ & 45 & 48 & 44 & 99 & 99 & 90 \\
\hline $\mathrm{E}$ & $5 \mathrm{mM} \mathrm{Mg}^{2+}+5 \mathrm{mM} \mathrm{Ca}^{2+}$ & 68 & - & - & - & - & - \\
\hline
\end{tabular}
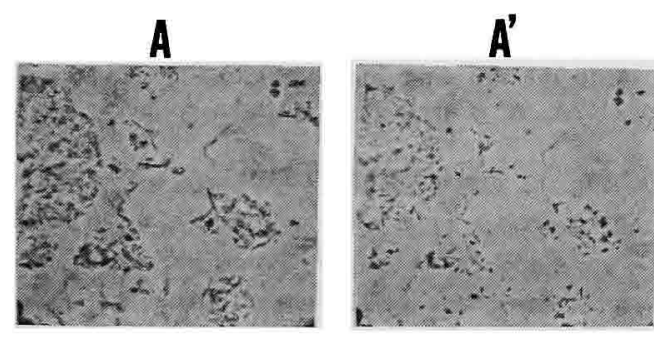

B
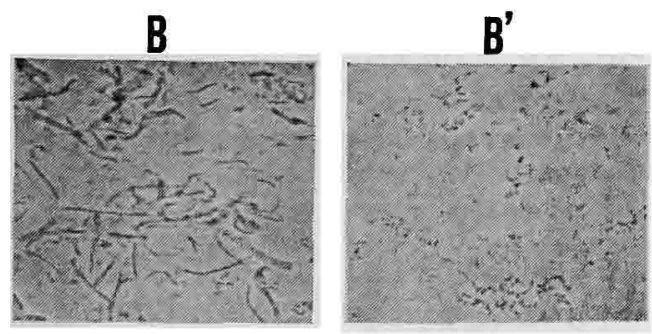

Fig. 11. Phase-contrast micrographs of fish myofibrils contracted by ATP.

The assay system for the contraction of myofibrils was principally the same as in Fig. 1. A drop of myofibrils suspension was placed on a slide glass and then a cover glass placed on it. A drop of ATP solution ( $\mathrm{pH} 7.0$ ) was instilled at one edge of a cover glass. Photographs were taken before (A and B) and after $\left(\mathbf{A}^{\prime}\right.$ and $\mathbf{B}^{\prime}$ ) addition of ATP.

A, A' (Carp); B, B' (Alaska pollack)

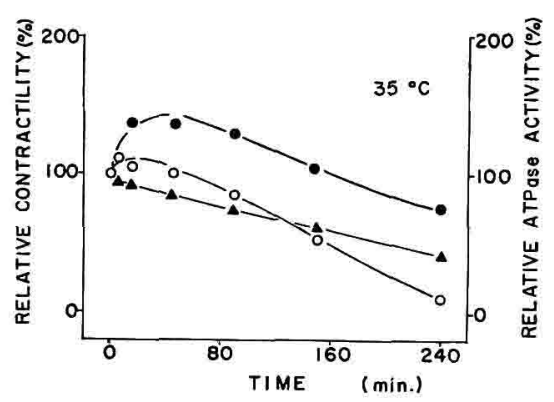

Fig. 12. Changes in the contractility and ATPase activity of carp myofibrils during incubation at $35^{\circ} \mathrm{C}$.

Incubation of myofibrils $(0.1 \mathrm{M} \mathrm{KCl}-40 \mathrm{mM}$ Tris- $\mathrm{HCl}, \mathrm{pH} 7.5$ ) was performed at the protein concentration of $4.5 \mathrm{mg} / \mathrm{ml}$ and at $35^{\circ} \mathrm{C}$.

The assay system for the contractility of myofibrils was the same as in Fig. 1. The volume of fibril layer in the assay system was measured by centrifugation at 1,000 rpm for 20 minutes. The demonstration of the contractility was the same as in the legend of Fig. 1. (O)

The ATPase activities of myofibrils under the same conditions as above, were measured (๑). The ATPase activity of myofibrils in the assay system containing $5 \mathrm{mM} \mathrm{CaCl} \mathrm{Clone}_{2}$ alone as divalent cation, was also measured at $2^{\circ} \mathrm{C}$ (A). 
お, Mf が変性すると, やはり集合体または凝集体と思 われる像が顕微鏡視野に現れるが，これは後述するよら にATPによつて収縮しなかつた。

加熱による筋原輚維の収縮率の変化 先ずュイ Mf $35^{\circ} \mathrm{C}$ で加熱したときの収縮率と ATPase 活性の変化 を検討した(Fig. 12)。それによると，この条件下におけ る Mf の $\mathrm{Mg}^{2+}$-ATPase 活性および収縮率の変化はい つれも二相性を示し, 初期にやや上昇し以後降下する曲 線となつた。さらに, 収縮率の変化は $\mathrm{Mg}^{2+}$-ATPase 活 性のそれより速く進行した。一方, $\mathrm{Ca}^{2+}$-ATPase 活性 (5 mM Ca ${ }^{2+}$ のみ存在) の変化は二相性を示さず，良く 知られるよらに一次反応にしたがつて失活した4)。Mfの $\mathrm{Mg}^{2+}$-ATPase の失活はその収縮率の低下と強く相関し ていることがここでも示されている。この結果は異なる 加熱温度および異なる魚類 Mf の場合においても同じで あつた。なお，上の実験で使用したコイ Mf の収縮率は $70 \%, \mathrm{Mg}^{2+}$ 打よび $\mathrm{Ca}^{2+}$-ATPase 比活性はそれぞれ 22

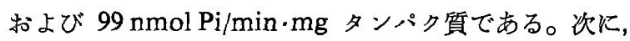
加熱による Mf の収縮率の変化を異なる魚種間で比較し た (Fig. 13)。ここにはコイ, マガレイ・スケトウタラ Mf の変化を示すが，これによるといずれの魚種の場合

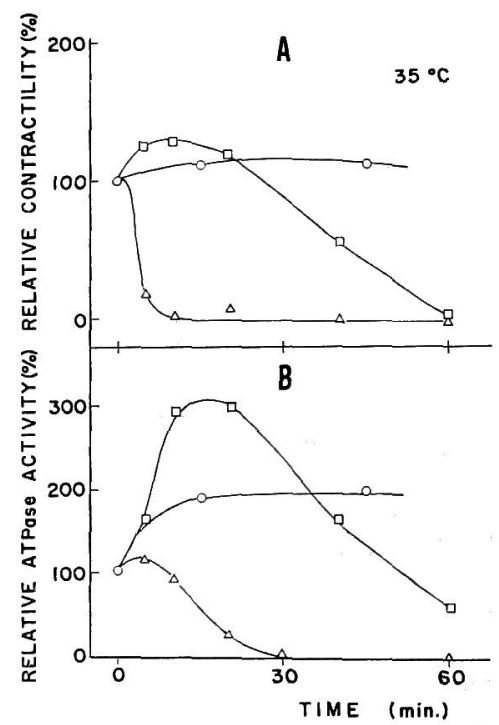

Fig. 13. Changes in the contractility and ATPase activity of fish myofibrils during incubation.

The incubation of myofibrils was performed as described in the legend of Fig. 12.

(A) The contractility of myofibrils was measured in the same assay system as in Fig. 12. (B) The ATPase activity under the same condition as in $\mathrm{A}$, was measured.

(O) Carp; ( $\square$ ) Flat fish (Magarei in local name); $(\triangle)$ Alaska pollack.

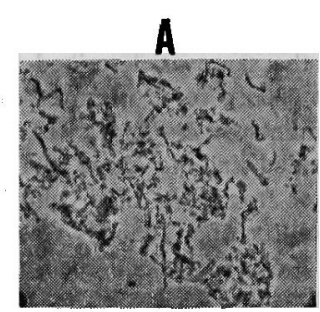

B

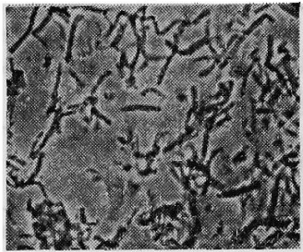

Fig. 14. Phase-contrast micrographs of incubated myofibrils before and after addition of ATP. Incubation of myofibrils $(0.1 \mathrm{M} \mathrm{KCl}-40 \mathrm{~mm}$ Tris- $\mathrm{HCl}, \mathrm{pH} 7.5$ ) was performed at $35^{\circ} \mathrm{C}$ for 30 minutes (Alaska pollack) or at $45^{\circ} \mathrm{C}$ for 120 minutes (Carp), respectively. The incubation was stopped by cooling in the ice water, and photographs were taken before (A and $B$ ) and after $\left(\mathbf{A}^{\prime}\right.$ and $\left.\mathrm{B}^{\prime}\right)$ addition of $\mathrm{ATP}$ according to the the same method as in Fig. 11.

A, A' (Carp); B, B' (Alaska pollack)

も Fig. 12 の結果と同様に，その収縮率拉よび $\mathrm{Mg}^{2+}$ ATPase 活性は二相性を示す変化曲線となつた（スケト ウタラの場合は変性が速すぎるため明瞭な二相性を示さ ないが， $30^{\circ} \mathrm{C}$ では明らかな二相性を示す)。また，収縮 率の变化は $\mathrm{Mg}^{2+}$-ATPase 活性の変化よりやや速く起こ つた。なお,ここの結果から Mf の温度安定性を推定する と，安定な方からコイ，マガレイ，スケトウタラとな

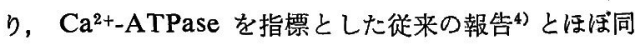
しとなつた。しかしこれらの変化曲線の再現性はあま り良くなく，Mf 標品ごとに変動する上，特に初期に見 られる活性化の度合も著しく変化した。この变動の原因 は不明である。なお，加熱した Mf はしばしば集合体 (もしくは凝集体)を形成するが，顕微鏡下で観察すると この像はATPによつて収縮しない (Fig. 14)。すなわ ち, ユイ Mf の場合は $40^{\circ} \mathrm{C}$ において 120 分後に( $\left.\mathrm{A}, \mathrm{A}^{\prime}\right)$, 不安定な魚稙として知られるスケトウタラ Mf の場合は $35^{\circ} \mathrm{C}$ で 15 分後 $\left(\mathrm{B}, \mathrm{B}^{\prime}\right)$ に収縮性を失なら。これによ ると, ATP を添加する前 $(A, B)$ と後 $\left(A^{\prime}, B^{\prime}\right)$ を比べ て形態的に大差が見られずこのような形態観察の結果 は収縮率の変化 (Fig. 13) と良く一致するすのであつた。 他の魚類 Mf についても同じ結果が認められている。 


\section{考察}

魚類の Mf に関する研究の中，特に取縮性に関する研 究は少ないため, 魚種, 筋肉部位, 鮮度执よび貯藏条件 などが M「の収箱率に及ぼす影響については明らかでな い。本実験では活魚なたは新鮮肉を使用したが，Mfの 収縮率は 65〜 75\% の範聿で標品ごとに異なる值を示し た(経験的には澌定誤差は数\%である)。Mf の調製に使

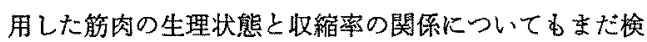
討を加えていないか，硬直前後の筋肉から得た Mf の ATPase 活性には差がないといら2。また，魚肉のホモ シナナイ゙に際して $0.1 \mathrm{M} \mathrm{KCl}(\mathrm{pH} 7.5)$ 溶液に EDTA を添加しても得られた Mf の収縮率は变らなかつた。一 方, Mf 標品中に笳小胞体(弛緩因子)が混入するとATP によつてかえつて膨閏 (弛楥) する現象も知られてお

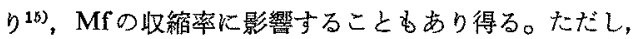
本笑跧で使用した Mf 標品は洗浄をかなりよくくりかえ しているので筋小胞体は残存していないと考えている。 著者らが主に使用した Mfは，先述したよらに必らずし す影微鏡的に均等な大きさの Mfではないが，ての生化 学的性質や収縮率の研究に供するためにはなんら支障が ないものであつだ。したがつて、一定量の魚肉を強くホ モジナイズし定量的に Mf 懸濁液に変えた後ての性質 (たとえは ATPase 全活性)を測定すると，これ虫供試 魚肉全体の性質を反映すると推定することができる。こ のような方法によつて魚肉の品質判定をする試みもすで に提出されている

BENDALL は ATPに上る Mf の収縮をストロボスコ ープを使つて，その容積の減少速度(沈降速度)から追 跡して出り，収縮は違心力が最大澾する前に非常に造 く䅂了与ると述べている2)。本研究では Mf の收繀速度 を笔蛋液の濁度変化として追䟽したが(Fig. 10), この変 化も非常に速くほ堙 1 分以内に終了するため, 正確な速 度を知るには反応に関する基礎的な条件検討が必要であ る。いずれにしても，本研究で行つた魯類 MfのATP に上る容積変化は明らか下筋肉の生理的な収樎能を反映 しており，妾た，Mf の加熱に際しては $\mathrm{Mg}^{2+}$-ATPase の失活上り速く変化するので，魚肉の品質を示す鋭敏な 指標の一として検討する価值があるら。一方，Mf の $\mathrm{Mg}^{2+}$-ATPase 活性はその収縮能と強く相関していると いら結果示したが，それがどすうな分子上の闍題で あるかは今後研究しなければならない。C $\mathrm{Ca}^{2+}$-ATPase 活性は収箱とは関連せず，発生するエネルギーは熱とし て消費されると言われる2。。したがって，この活性はそ の中に含まれるミオンン全量に相当する数値亡言兄よ
ら。なお，加熱際して Mf $の \mathrm{Mg}^{2+}$-ATPase 活性は二 相性を示す山型の変化曲線を示すが，活性の半減期（活 性が初めの 50\% に達する束での時間) を測定して变性 の速さを比较した実験報告るすでにある゙る。しい，著 者らの検討した結果によると、この变化曲楾执よび半減 期は㬰験ごとに，また標品ごとにかなり梦勤し再現性に そしいので激密な比較は不可能であつだ。

本研究は文部省科学研究費補助金によつて行われた。 ここに記して謝意を表する。

\section{文献}

1) 加藤 登 -内山 均 - 嚗本志朗 - 新井健一：日 水誌, 43, 857-867 (1977).

2) J.R. Bendall: Muscles, molecules and movement, Heinemann Educational Books Ltd. London, 1969, pp. 42-57.

3) I. A. Johnston, N. Frearson, and G. Golpspink: Biochem. J., 133, 735-738(1973).

4) 内山 均 - 加藤 登 - 工藤雄司 - 新井揵一：日 水誌，44，491-497 (1978).

5）橋本昭彦・新井健一：日水誌，44，1389-1393 (1978).

6) I.A. Johnston, N.J. WALESBY, W. DAvidSON, and G. GoldsPINK: Nature, 254, 74-75 (1975).

7) I.A. Johnston and G. Goldspink: Nature, 257, 620-622 (1975).

8) S.K. Sung, T. Ito, and T. Fukazawa: $J$. Food Sci., 41, 102-107 (1976).

9) K. Takahashi, T. Fukazawa, and $T$. YASU1: J. Food Sci., 32, 409-413 (1967).

10) A. Oplatka, J. Borejdo, and H. Gadasi: FEBS Letters, 45, 55-58 (1974).

11) R. YanG, A. OKitani, and M. FuJimaki: Agr. Biol. Chem., 34, 1765-1772 (1970).

12) S.V. Perry: Biochem. J., 48, 257-264 (1951).

13）高橋泰常：生化学の領域に㧍ける光電比色法各 論 2 (関根隆光・笹川泰次・森田茂広・木村德 次・會富一興編)，南江堂，東京，1962，pp. 13-14.

14) A.G. Gornall, C.T. Bardwill, and M.M. DAvid: J. Biol. Chem., 177, 751-766 (1949).

15) 丸山工作：筋収縮の制御，岩波畫店，東京， 1976, p. 71.

16) D.W. Stanley and G.W. DeVillafranca: Comp. Biochem. Physiol., 38, 733-742(1971).

17) 高士令二: 日水誌，39，197-205 (1973).

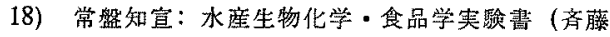
恒行・内山均・梅本 滋・河端俊治 糄), 恒 星社厚生閣, 東京, 1974, pp. 170-178.

19) 加藤 登・野㥓 恒・小松一宫・新井健一：日 水誌, 45, 1027-1032 (1979). 